\title{
THE STRANGE CASE OF FIELD MARSHAL SIR JOHN DILL
}

\author{
by
}

\section{ALEX DANCHEV *}

Field Marshal Sir John Dill held the most important military offices of the Second World War. In the supreme crisis of May 1940, as the evacuations from Dunkirk were about to get under way, he was made Chief of the Imperial General Staff (CIGS). In the critical instant of December 1941, as the Japanese attack on Pearl Harbor reverberated around the world, he was translated to the United States to become head of the British Joint Staff Mission in Washington and senior British member of the newly created Combined Chiefs of Staff committee, the executive agency of the Anglo-American war effort. He died in harness on 4 November 1944, universally mourned throughout official America. President Franklin D. Roosevelt called him "not only . . . a great soldier and a great friend, but ... the most important figure in the remarkable accord which has been developed in the combined operations of our two countries". His monument in Arlington National Cemetery, the American Valhalla, marks his apotheosis. $^{1}$

This was a peculiar triumph. Throughout $1940-41$ the common belief in Downing Street and Whitehall was that the CIGS was clearly "worn out", if not certifiably ill. In the contemporary idiom, Dill was said to be "a tired man". ${ }^{2}$ This euphemism suggested not so much tiredness as complete exhaustion. The deliberate implication was that he was a spent force, constitutionally incapable of standing up to Winston Churchill-the need to "stand up" to the delinquent Prime Minister was another instance of accepted usage - and therefore in the final analysis derelict in his duty. ${ }^{3}$ As early as July 1940 , Churchill himself complained: "I do not think we are having the help from General Dill which we hoped for at the time of his appointment, and he strikes me as being very tired, disheartened, and over-impressed with the might of Germany." 4 These judgements, or aspersions, recalled even earlier ones. In October 1937, Basil Liddell Hart's influential advice to the then Secretary of State for War was that, after years of outstanding promise, Dill had most definitely "gone off" as a consequence of various

* Alex Danchev, Ph.D., Department of International Relations, University of Keele, Keele, Staffs. ST5 5BG.

\footnotetext{
${ }^{1}$ Alex Danchev, Very special relationship, London, Brassey's, 1986, pp. 145-6.

${ }^{2}$ Churchill to Nye, 13 November 1941, quoted in Anthony Harrison, Archie Nye, London, privately published, 1980, p. 12; Ismay to Churchill, 10 November 1949, Ismay Papers, II/3/188a, Liddell Hart Centre for Military Archives, King's College, London [hereafter KCL].

${ }^{3}$ Alex Danchev, 'Dilly-dally, or having the last word', J. contemp. Hist., 1987, 22: 21-44.

${ }^{4}$ Churchill to Eden, 10 July 1940, quoted in Martin Gilbert, Finest hour, London, Heinemann, 1983. p. 658 .
} 


\section{Alex Danchev}

accidents and illnesses. ${ }^{5}$ The Secretary of State, Hore-Belisha, was only too ready to believe him. A pattern of doubt about Dill's physical capacities had already been created.

The doubters subsequently received powerful reinforcement from the insidious nature of Dill's terminal illness-aplastic anaemia. ${ }^{6}$ At the time, the last word on the subject was M. W. Wintrobe's Clinical hematology. "A waxy pallor is usually well marked by the time attention is drawn to the illness ... The chief mainstay of treatment is blood transfusion. This serves to support the patient until and in the hope that his bone marrow may be able to form cells once more." Wintrobe found that patients had been kept alive for as long as nine years, but noted that "in the classical idiopathic form of aplastic anaemia, its course is progressive, inexorable and more or less rapidly fatal in spite of blood transfusions. Death ensues in the course of a few weeks or life may linger as long as six months." 7 The discovery of Dill's anaemia gives rise to a number of intriguing questions. When did it take hold? For how long was his work in key posts affected, and how seriously? Could he have been suffering from it or sickening for it in 1940 or even earlier? Would it explain his much-disparaged performance as CIGS, adding new meaning to being "tired" or "worn out"? When was it diagnosed? Who was told? Did Churchill know? Did Dill?

The conventional wisdom on Dill tends to be retrospective: later knowledge of his anaemia is used to underpin an analysis of continuous decline dating from 1931-32, paradoxically coincident with his assumption of increasingly onerous responsibilities. On this analysis he was desperately weak (in more than one sense) when he left the office of CIGS in December 1941, if not when he entered it in May 1940. He was able to recúperate somewhat in Washington, but never fully to recover. His death in November 1944 at the age of 62 was remarkable only for being so long postponed. His decline is ascribed, firstly, to congenital defects of character and personality, encapsulated in Lord Moran's feline observation that he lacked "the he-man stuff", and exposed by working with the profoundly antipathetic Churchill; ${ }^{8}$ secondly, to the misfortune of his precipitate and unhappy first marriage, ended only when his wife died in December 1940 after a long series of paralytic strokes; ${ }^{9}$ and above all to deterioration in his own health consequent on the presumed onset of the anaemia, exacerbated by a number of relatively serious riding accidents, notably in the 1931 Drag Hunt at the Staff College, Camberley, in 1939 at Aldershot, and in 1943 in India. ${ }^{10}$

Much of Dill's interior life inevitably remains speculative, but there is unusually detailed and authoritative evidence on his injuries and illness. The evidence derives from a noteworthy source, the distinguished neurologist Foster Kennedy, known to

\footnotetext{
${ }^{5}$ Liddell Hart diary, 1 October 1937, quoted in Basil Liddell Hart, Memoirs, vol. 2, London, Cassell, 1965, p. 32.

6 I am grateful to Lord Butterfield and Dr Hugh L'Etang for discussion of Dill's case, elucidation of certain clinical aspects, and guidance on the literature.

${ }^{7}$ M. W. Wintrobe, Clinical hematology, Philadelphia, Lea \& Febiger, 1942, pp. 350, 358.

${ }^{8}$ Moran diary, 1 January 1942, quoted in Lord Moran, Churchill: the struggle for survival, London, Constable, 1966, p. 20.

${ }^{9}$ Alex Danchev, 'Field Marshal Sir John Dill: the early years', J. Soc. Army Hist. Res., 1989, 67: 28-39.

${ }^{10}$ Hospital records, Dill War Office file, Ministry of Defence.
} 


\section{The strange case of Sir John Dill}

the present generation for the syndrome which bears his name. Kennedy was Dill's cousin and boyhood playmate on dismal, rain-sodden afternoons in the Botanical Gardens of Belfast. As he wrote after Dill's death, "we grew up together in the North of Ireland like brothers, he the elder. Our lives took us far apart, but the past three years made us as close as men can be. I have never felt the death of anyone in my life so much." 11 Foster Kennedy was a most remarkable man, as the range of his acquaintance and the sheer delight of his copious correspondence abundantly testify. He had emigrated to New York in 1910, many years before Dill found his way to Washington. There he pursued a brilliant career, in 1919 succeeding Charles Dana as Professor of Neurology and head of the neurological service at Bellevue Hospital. Ensconced in a capacious house in Sutton Square, it seemed that he knew everybody from Ameila Earheart to Jerome Kern. He treated Winston Churchill after a celebrated traffic accident; he was consulted by Franklin Roosevelt. He captivated them all. "With his buoyant step and cheerful appearance, his black Homburg hat set at a jaunty angle, he was for many people what the elderly soda-jerk at our local drug store once said of him: "the most beautiful man I ever saw'."12

Prompted by the onward march of external events, Dill and Kennedy had resumed an increasingly intimate correspondence in the late 1930s; once they were both in the United States they were able to meet regularly and share everything. The neurologist became Dill's confessor and friend, and was certainly the man who knew most about him. He began to take an active professional interest in his cousin's health in early 1941, when Dill was still CIGS. At Kennedy's instigation, the Harley street physician Lord Horder persuaded a reluctant Dill to undergo a thorough examination on 28 May 1941. Horder wrote privately of the outcome:

I am glad to be able to report favourably. But he was definitely in need of support, morally in the main. "Gouty", with a tendency to hyperpiesis [high blood pressure], and "irritable" heart whose extra-systoles [irregular pulse] made him a little anxious. Leading an impossible life, excluding all sorts of physical exercise, and even of light fare. Concerning these last he made certain promises to mend his ways-and will, I think, in his own and (especially) in the national interest. ${ }^{13}$

None of these conditions was unusual. After Dunkirk and the imminent threat of invasion, after a year of Churchill's small-hours scheming, after three exhausting months of travel in the Mediterranean canvassing Greek and Turkish support against the Axis, this report gave no cause for alarm about any inexorable deterioration in Dill's health.

From 1942 Foster Kennedy could, if necessary, do the examining himself. He saw no reason to do so until February 1943, when Dill returned from travelling in India and China with a left direct inguinal hernia ("a good sign of tissue fatigue", as Kennedy noted later), having taken a fall whilst out pig-sticking with General Wavell. The

\footnotetext{
${ }^{11}$ Kennedy to Pool, 2 March 1945, Foster Kennedy Papers, privately held.

12 Isabel K. Butterfield, The making of a neurologist, Hatfield, Stellar Press, 1981, p. 13.

${ }^{13}$ Horder to Kennedy, 30 May 1941, Kennedy Papers.
} 


\section{Alex Danchev}

hernia operation was performed satisfactorily in April 1943 but was followed by "a stormy convalesence, persistent retention [of urine] and cystitis for some weeks, together with two pulmonary infarcts". The situation was not helped by Dill's participation in the Washington Conference of May 1943 immediately after coming out of hospital, in spite of having a temperature of 101. By the end of June, however, he appeared to be completely restored. During the next few weeks he travelled to London, Quebec, Cairo, Tehran, and all over the United States. Nevertheless, looking back, Kennedy was inclined to see this episode as the first break in Dill's health. ${ }^{14}$

In January 1944 a small growth "of very low malignancy" was successfully removed from his lower lip by Dr Henry Cave. "This, of course, was a matter of anxiety to him, but though there was a threat it had no real gravity." From February 1944 Dill lost blood from the bowel but said nothing to anyone until the end of May, when a large haemorrhage induced him again to approach his friend. This condition prevented him from joining the other members of the Combined Chiefs of Staff in London in June, to celebrate the D-Day landings and plan for the future. Suddenly, he was virtually incapacitated..$^{15}$ The haemorrhoids were easily dealt with, but it was noticed that his blood was very poor in platelets and reticulocytes. It soon became clear that blood transfusions were not having the expected regenerative effect: his blood count fell back to its pre-transfusional level after only four or five days. Kennedy and his colleagues did a sternal puncture and found that the bone marrow was hypoplastic. They recognized the classic symptoms of aplastic anaemia. "We realized in July [1944] that he would probably not recover." 16 Dill spent June, July, and August in hospital or rest-home but in early September 1944 returned to his desk. $\mathrm{He}$ insisted on taking part in the second Quebec Conference the same month and continued to function effectively "half-time" until the inevitable collapse at the end of October, when he began to bleed from the mucous membranes. During the summer, depressed, he contemplated resignation but was dissuaded by Kennedy, who judged that to work half-time was better for the Alliance and for the patient himself than not to work at all. ${ }^{17}$

The full implications were not spelled out to London until after Dill's collapse on 30 October. Information was conveyed unofficially to General Ismay in the War Cabinet Offices by the secretariat of the Joint Staff Mission in Washington. It was of course immediately obvious in June 1944 that Dill was seriously ill; in late August it was equally obvious that "he must take it very quietly for some time to come". But the premiss throughout the summer was that he could and would recover. ${ }^{18}$ Seeing him for the first time in several months at Quebec, the British party were shocked at his physical deterioration-the weight-loss and the characteristic waxy pallor had

\footnotetext{
${ }^{14}$ Kennedy to Longcope and Riddoch, 25 September and 27 November 1944, Kennedy Papers.

15 Ibid.

16 Ibid.

${ }^{17}$ Dill to Brooke, 7 July and 1 August 1944, Alanbrooke Papers, 14/39/D and F, KCL; Kennedy to Patterson, 29 November 1944, Kennedy Papers.

${ }_{18}$ Redman to Ismay, 20 July 1944, Alanbrooke Papers, 14/39/E, KCL; Cornwall-Jones to Ismay, 25 August 1944, CAB 120/144, Public Record Office, Kew.
} 


\section{The strange case of Sir John Dill}

taken hold. ${ }^{19}$ At the start of the conference Dill asked Moran-present in his capacity as Churchill's personal physician-"if I would come to his rescue if he needed me".

He then took out of his pocket a crumpled bit of paper and gave it to me. It was a report on the last two examinations of his blood. I saw at a glance that he was not reacting to treatment, and I doubt if he will last long. I wonder if he knows? ${ }^{20}$

Dill did not know. He too was not told the full implications in the summer. He may never have realized them. Notwithstanding his encounter with Moran, Churchill and the Chiefs of Staff explicitly endorsed Kennedy's judgement. Much to his delight, Dill was confirmed in post. By October, ironically, he was "hoping to get really well-in time". 21 A few days later he was dead.

In the strange case of Field Marshal Sir John Dill, Foster Kennedy's impressively detailed evidence is unimpeachable. 1944 marked the onset of Dill's anaemia. It was indeed insidious but owing to its coincidence with haemorrhoids was diagnosed in July of that year. Given the thoroughness of Kennedy's monitoring and the rigorous examinations of early 1943 (because of the hernia) and early 1944 (because of the growth), it is almost inconceivable that he was already suffering from it in Washington before 1944, still less in London before 1941. If he appeared weak or lethargic as CIGS the explanation must be sought elsewhere-very often in the writing of what might be called the Churchillian school of history. ${ }^{22}$ In the United States he was not seriously impaired until June 1944. After that, as Kennedy feared, he never really recovered. But he did return to work, and worked on until he died, literally bone-weary.

${ }^{19}$ Arthur Bryant, Triumph in the West, London, Collins, 1959, p. 277; Admiral Lord Cunningham, A sailor's odyssey, London, Hutchinson, 1951, p. 612; Gordon Macready, In the wake of the great, London, Clowes, 1965, pp. 184-5.

${ }^{20}$ Moran diary, 12 September 1944, quoted in Moran, op. cit., note 8 above, pp. 176-7.

${ }^{21}$ Dill to John Dill, 27 October 1944, Dill Papers, 5/6, KCL.

22 Monumentally, his authorized biographer Martin Gilbert. See the discussion in Danchev, op. cit., note 3 above. 